\title{
Considerations for boreal mixedwood silviculture: A view from the dismal science
}

\author{
by Glen W. Armstrong'
}

\begin{abstract}
Since the end of the twentieth century, there have been some notable changes in the economic climate facing forest products companies operating in the boreal mixedwood forest in Canada: low product prices, a strong Canadian dollar, and increasing recognition of the importance of non-timber forest values are major challenges that must be faced by forest managers and provincial governments. In response to these challenges, foresters and governments may need to rethink the objectives of forest management as stated in policy, and to rethink the silviculture prescriptions applied to the forest. This rethinking may well lead to a forest with less annual production (at least in terms of softwood volume), but with greater economic value for timber production. I present results of financial analysis of several alternative management scenarios for the mixedwood component of the Boreal Plains ecozone, and conclude that only very low cost silvicultural prescriptions make sense when silvicultural expenditures are viewed as an investment in future stands. If these silvicultural expenditures are viewed as a cost of current harvesting, they may be large enough to turn a profitable timber harvesting opportunity into a money-losing one.
\end{abstract}

Keywords: economics, financial analysis, boreal forest, white spruce, trembling aspen, Faustmann, land expectation value, soil expectation value, bare land value

\begin{abstract}
RÉSUMÉ
Depuis la fin du XXe siècle, plusieurs changements importants se sont produits dans lenvironnement économique que doivent affronter les compagnies forestières œuvrant dans les forêts mixtes boréales du Canada. Les gestionnaires forestiers et les gouvernements provinciaux sont confrontés notamment : aux faibles prix pour les produits, à la vigueur du dollar canadien et à une prise de conscience accrue sur limportance des valeurs non ligneuses de la forêt. Devant ces défis, les forestiers et les gouvernements pourraient être forcés de revoir les objectifs de leurs politiques d’aménagement forestier et de reformuler les prescriptions sylvicoles appliquées en forêt. Ce réexamen pourrait bien se traduire par une forêt moins productive (au moins sur le plan du volume de résineux), mais offrant une meilleure valeur économique pour la production de billots. Je présente ici les résultats d’une analyse financière portant sur différents scénarios daménagement alternatifs pour les forêts mixtes de la zone écologique des plaines boréales; jen arrive à la conclusion que seules les prescriptions sylvicoles très peu dispendieuses ont du sens si les frais de sylviculture sont devaient être considérés comme un investissement dans les peuplements à venir. $\mathrm{Si}$ ces frais de sylvicultures sont inclus comme coûts de la récolte actuelle, ils pourraient être si élevés qu'ils rendraient déficitaire ce qui autrement se serait avéré une bonne occasion de récolte.
\end{abstract}

Mots clés : économie, analyse financière, forêt boréale, épinette blanche, peuplier faux-tremble, Faustmann, valeur d’attente du territoire, valeur d’attente du sol, valeur des terres nues

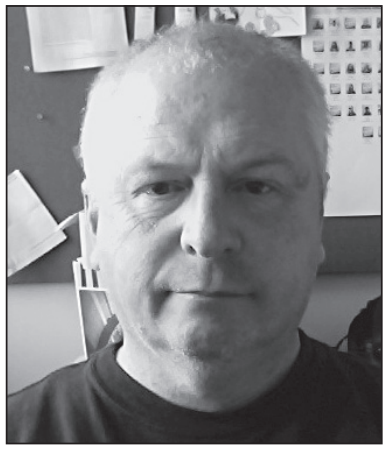

Glen W. Armstrong

\section{Introduction}

Between 1978 and 1982 I was an undergraduate student at the University of Alberta working towards a B.Sc. in Forestry. I remember being impressed by (what seemed to me) the firm conviction of my professors that maximum sustained yield of timber (and perhaps also range, water, recreation, and wildlife) was a laudable goal, and that silvicultural practices such as site preparation, planting, and vegetation control were good ways of helping to achieve this. To me, this seemed like a statement of a good and just moral position. One of my professors liked to say lwe do not inherit the forest from our ancestors; we borrow it from our children".

I learned later that a slight variant of this quotation is usually attributed to Chief Seattle of the Duwamish and Suquamish tribes from Puget Sound in modern-day Washington State. He is said to have made this statement in a long and wide-ranging speech given in 1854 or 1855 . The story is probably apocryphal (Clark 1985), but the words are powerful and I believe they underlie the moral code of many foresters practising today.

For much of my time as an undergraduate student, aspen was considered a weed species. It was essentially valueless, and competed with valuable white spruce. Douglas Mead (1977) published an article in The Forestry Chronicle entitled "Aspen - The Ugly Duckling" in which he exhorted forest managers to "actively manage aspen stands to produce aspen at the next harvest". Ondro (1991) documented an increase in poplar (mostly aspen) harvest in Alberta from $132000 \mathrm{~m}^{3}$ in the fiscal year 1980-1981 to $2477000 \mathrm{~m}^{3}$ in 1990-1991, largely as a result of the establishment of a number of oriented strand

${ }^{1}$ Department of Renewable Resources, University of Alberta, Edmonton, Alberta T6G 2H1. E-mail: gwa@ualberta.ca 
board (OSB) plants and hardwood pulp mills. In 2010, the hardwood (mostly aspen) harvest in Alberta was 5831000 $\mathrm{m}^{3}$ (CCFM 2012): this was a 40 -fold increase in aspen harvest volume over a 30 -year period.

Despite this huge increase in the importance of aspen to the forest products sector in Alberta, forest regeneration standards are still heavily biased in favour of creating pure coniferous stands after harvest (Lieffers et al. 2008). As did Lieffers et al. (2008), I will focus my discussion on boreal mixedwood forests in Alberta. Their description of succession in Alberta boreal mixedwoods is very relevant to the current study and is reproduced, in large part, below.

This forest is naturally a complex mixture of coniferous and deciduous trees; it is also an important source of fibre, and similar forests are found over a wide area of Canada (Rowe 1972). The productive upland forests are found on mesic to subhygric moisture regimes and medium to rich nutrient regimes in the boreal mixedwood and lower foothills natural subregions ... in the boreal mixedwood 18a and 19a sections (Rowe 1972). Early in development, fire-origin boreal mixedwoods are dominated by deciduous species (aspen, balsam poplar and paper birch), with lodgepole pine an occasional part of the overstory mix in the lower foothills. Shade-tolerant species such as white spruce, black spruce and/or balsam fir usually establish under the deciduous trees, and as the spruce attain greater maximum height and live longer than the deciduous species, they eventually dominate the stand (Lieffers et al. 1996). Because white spruce is a masting species, a seed source is not always available; as a result the spruce may recruit immediately after disturbance or some years later (Peters et al. 2006), depending on the timing of the mast.... Mixedwood ecosites are therefore capable of growing pure coniferous or deciduous stands, or stands containing intimate mixtures of coniferous and deciduous species. Due to succession, the composition of a stand growing on mixedwood ecosites can change greatly over time. The stochastic nature of white spruce seed dispersal and its slow juvenile growth rate has meant that it is usually regenerated through site preparation and planting after harvest, at considerable cost.

In summary, Alberta boreal mixedwood stands subjected to a stand-replacing disturbance (e.g., fire or harvest) often regenerate naturally to aspen-dominated stands, and early establishment of a pure white spruce stand would usually require silvicultural treatment. It is common for the spruce component of boreal mixedwood stands to increase over time, as more spruce is established and aspen dies.

The policy of replacing harvested white spruce stands with quickly established pure (or nearly pure) spruce plantations is expensive and will put regenerating stands on a very different successional trajectory than what would have occurred naturally (Lieffers et al. 2008). Lieffers et al. (1996) and Bergeron et al. (1999) proposed some alternative silvicultural strategies that could be used to allow forest management to better emulate natural disturbance than the clearcut and plant strategy currently in place across much of the boreal forest of Canada.
Since the end of the twentieth century, there have been some notable changes in the economic climate facing forest products companies operating in the boreal mixedwood forest in Canada: low product prices, a strong Canadian dollar, and increasing recognition of the importance of non-timber forest values are major challenges that must be faced by forest managers and the landowners. Forest economists occasionally revisit the economics of clearcut and plant silviculture in the boreal forest (e.g., Armstrong and Phillips 1989, Rodrigues 1998, Adamowicz et al. 2003), but their analysis seems to have had little impact on reforestation policy.

Perhaps now, with a different economic climate facing the forest products industry, is a good time to revisit the economic analysis of silvicultural investment in the boreal forest. This study is an attempt to do just that.

\section{Forest Economics 101}

A basic input to most analyses of silvicultural investments is a timber yield table expressing the relationship between stand age and expected timber yields. Armstrong developed a spreadsheet-based yield table generator for Alberta which will be used here (Armstrong 2011). Armstrong's conifer yield curve for $\mathrm{C}$ crown closure, pure white spruce stands, on good timber productivity rating stands in Alberta is presented in Fig. 1. The mean annual increment (MAI) for this yield curve reaches a maximum of $2.8 \mathrm{~m}^{3} \cdot \mathrm{ha}^{-1} \cdot \mathrm{year}^{-1}$ at 75 years since disturbance. I will use this yield curve to represent the growth of white spruce on a boreal mixedwood stand that has received silvicultural treatment with the goal of quickly establishing a pure white spruce stand.

For the purposes of the financial analysis that follows, I will assume that the stand will be managed for lumber

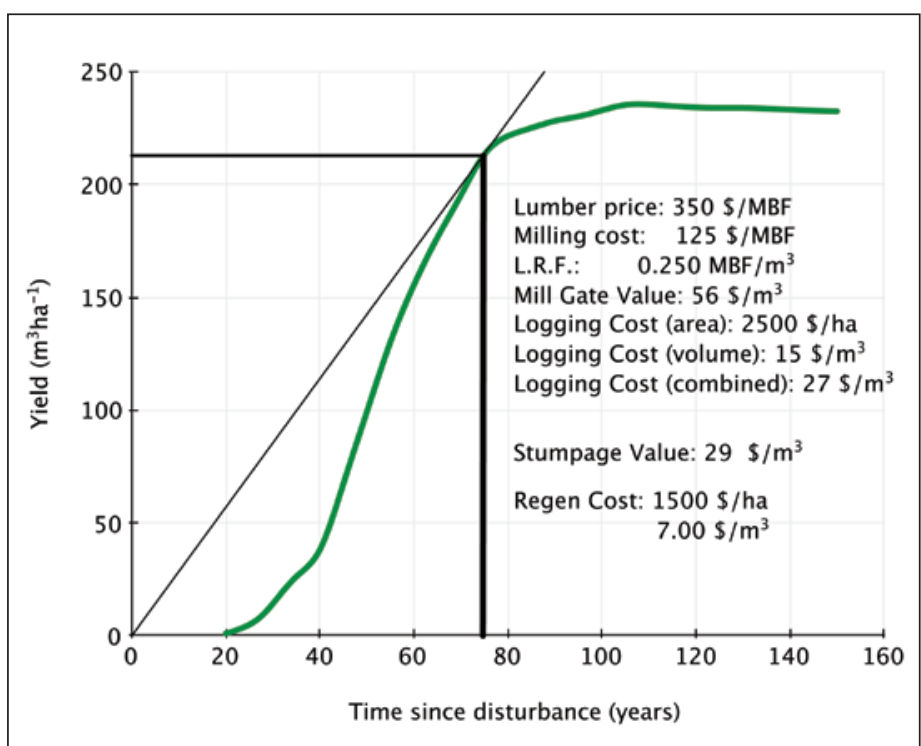

Fig. 1. Yield curve for coniferous volume of a $C$ crown closure pure white spruce stand on a good timber productivity rating site in Alberta showing the age of culmination of mean annual increment, including an example value calculation when silviculture expenditures are viewed as a cost of harvesting. The mean annual increment (MAl) for this yield curve reaches a maximum of $2.8 \mathrm{~m}^{3} \cdot \mathrm{ha}^{-1}$.year-1 at 75 years since disturbance. I will use this yield curve to represent the growth of white spruce on a boreal mixedwood stand that has received silvicultural treatment with the goal of quickly establishing a pure white spruce stand. 
production. The selling price of lumber is taken to be 350 Canadian dollars (CAN\$) per thousand board feet (MBF), the cost of converting logs at the mill gate to lumber ready for sale is assumed to be CAN $\$ 125 / \mathrm{MBF}$ and the lumber recovery factor is assumed to be $0.250 \mathrm{MBF} / \mathrm{m}^{3}$ of logs. The derived residual value (Davis et al. 2001) for logs at the mill gate is $(350-125) \times 0.250=\mathrm{CAN} \$ 56.3 / \mathrm{m}^{3}$. Assuming a fixed logging and log haul cost of $2500 \mathrm{CAN} \$ /$ ha and a variable cost of CAN $\$ 15 / \mathrm{m}^{3}$ for the $209 \mathrm{~m}^{3} \cdot \mathrm{ha}^{-}{ }^{1}$ to be harvested at an age of 75 years, the total delivered wood cost is CAN\$27/ $\mathrm{m}^{3}$. Subtracting the delivered wood cost from the mill-gate residual value leaves a stumpage value of CAN $\$ 29 / \mathrm{m}^{3}$ for the standing trees.

In Alberta, many companies view regeneration costs as a cost of harvesting. This makes some sense as future timber harvest rights are tied to regeneration performance through reforestation requirements. In order to ensure regeneration of pure white spruce stands in the boreal mixedwood, many companies prescribe a silvicultural regime involving site preparation, planting, and herbicide applications.

Such a silvicultural prescription costs in the neighbourhood of CAN $\$ 1500 /$ ha, or about CAN $\$ 7 / \mathrm{m}^{3}$ for the stand represented here. (P.G. Comeau, Professor, Renewable Resources, University of Alberta, personal communication, 2012). As CAN $\$ 7 / \mathrm{m}^{3}$ is considerably less than the CAN $\$ 29 /$ $\mathrm{m}^{3}$ stumpage value, a company could still make money with this silviculture expenditure. A graphical representation of this point of view is presented in Fig. 1.

An economist, on the other hand, is more likely to view a silvicultural expenditure as an investment in regenerating a stand than as a cost of harvesting the existing stand. The economist would likely calculate the land expectation value (LEV) given assumed streams of cost and revenues associated with the silvicultural investment and the growth and harvest of the resulting stand and its successors. The LEV (also known as bare land value and soil expectation value) is the value of forest land for growing timber crops immediately following the harvest of a stand: that is, before any site preparation or other post-harvest silvicultural treatments are applied. The optimal economic rotation age is the harvest age that maximizes LEV (Faustmann 1849).
The LEV can be calculated as

[1]

$$
\frac{L E V=\left(P-C_{v}\right) V(T)-C_{a}-(1+i)^{T} C_{r}}{(1+i)^{T}-1}
$$

where $P$ represents the mill-gate value of $\operatorname{logs}, C_{v}$ and $C_{a}$ represent the variable $\left(\mathrm{CAN} \$ / \mathrm{m}^{3}\right)$ and fixed costs (CAN $\$ /$ ha) of harvesting and $\log$ haul, $C_{r}$ represents reforestation costs (CAN $\$ / \mathrm{ha}), V(T)$ represents the yield $\left(\mathrm{m}^{3} \cdot \mathrm{ha}^{-1}\right)$ of the stand at the rotation age $\mathrm{T}$ (years), and i represents the decision maker's discount rate. The LEV maximum is -CAN1356\$/ha at a rotation age of 65 years. This calculation is startling to most of the foresters I have shown it to. Given reasonable assumptions about costs, revenues, and discount rate, the value of forested land in Alberta for growing pure white spruce stands, using the standard silvicultural prescription, is highly negative. The land is worse that worthless for growing timber, given this silvicultural prescription. This is surprising news to foresters who have been trained to believe that silvicultural expenditures are morally just and good.

Some readers may dispute my claim that these price, cost, and yield assumptions are reasonable. To address this concern, I present the results of a sensitivity analysis in Table 1. The sensitivity analysis suggests that it would require an increase in lumber prices from CAN\$350/MBF to CAN\$937/MBF, a decrease in reforestation costs from CAN $\$ 1500 /$ ha to 209 CAN\$/ha, a decrease in discount rate from $5 \%$ to $1.9 \%$, or an increase in yields by a multiplicative factor of 4.56 to result in a non-negative LEV. All of these new values appear far less reasonable to me than my baseline assumptions do.

The example presented here is interesting in that what is clearly a bad financial investment in future stands might make good financial sense from the point of view of a forest products company, if harvesting rights are tied to reforestation regulations requiring regeneration of coniferous timber. This concept is very closely related to the allowable cut effect described by Schweitzer et al. (1972).

Table 1. Sensitivity analysis for land expectation value (LEV) calculations. The results show the value that a parameter must be changed to in order to increase the calculated LEV to zero, changing one parameter at a time. The "yield multiplier" represents a constant by which the yield table is multiplied. Results for fixed cost of logging, variable cost of logging, and reforestation cost are not presented as no positive value could be found which increases the LEV value to zero.

\begin{tabular}{|c|c|c|c|c|c|}
\hline \multirow[b]{2}{*}{ Parameter } & \multirow[b]{2}{*}{ Base } & \multicolumn{4}{|c|}{ Parameter changed in sensitivity analysis } \\
\hline & & Lumber price & $\begin{array}{l}\text { Reforestation } \\
\text { cost }\end{array}$ & $\begin{array}{l}\text { Discount } \\
\text { rate }\end{array}$ & $\begin{array}{c}\text { Yield } \\
\text { multiplier }\end{array}$ \\
\hline Lumber price (CAN\$/MBF) & 350 & 937 & - & - & - \\
\hline Milling cost (CAN\$/MBF) & 125 & - & - & - & - \\
\hline Fixed cost of logging (CAN\$/ha) & 2500 & - & - & - & - \\
\hline Variable cost of logging $\left(\mathrm{CAN} \$ / \mathrm{m}^{3}\right)$ & 15 & - & - & - & - \\
\hline Reforestation cost $\left(\mathrm{CAN} \$ / \mathrm{m}^{3}\right)$ & 1500 & - & 209 & - & - \\
\hline Discount rate & $5 \%$ & - & - & $1.9 \%$ & - \\
\hline Yield multiplier & 1 & - & - & - & 4.56 \\
\hline Land expectation value (CAN\$/ha) & -1356 & 0 & 0 & 0 & 0 \\
\hline
\end{tabular}




\section{Further Exploration of the Lumber Price Assumption}

Fig. 2 shows how average annual lumber prices (in USD/ MBF) changed between 1996 and 2008. They exhibit a general downward trend. The story is more interesting when the exchange rate between the US and Canadian dollars (US\$ and CAN\$, respectively) and the general inflation rate in Canada are taken into account. The real price of lumber in 2002 dollars as seen by Canadian producers decreased by about 50\% from about CAN\$625/ MBF in 1996 to about CAN\$240/MBF in 2010. This undoubtedly has a large effect on the profitability of Canadian lumber manufacturers. If lumber price is set to CAN\$250/MBF for the stumpage value calculation in our example, the stumpage value decreases from CAN $\$ 29 / \mathrm{m}^{3}$ at a lumber price of CAN $\$ 350 / \mathrm{MBF}$ to CAN $\$ 4 / \mathrm{m}^{3}$. This is less than the required reforestation expenditures of about CAN $\$ 7 / \mathrm{m}^{3}$. Given these assumptions, reforestation expenditures are no longer just a bad investment forced on companies by government policy, but are actually costs than can turn a profitable harvesting operation into one that loses money.

This may seem like an academic exercise, but the harsh reality is reflected in trends in Crown timber revenue (Fig. 3) and harvest volumes (Fig. 4) across Canada. The contribution of the forest sector to provincial treasuries is down substantially, and harvest volumes in 2009 was at about two-thirds of the 1995 levels, which reflects a large number of permanent and temporary mill closures.

\section{Inexpensive Silviculture}

The main problems with the stand establishment treatments required by conifer regeneration standards in the boreal mixedwoods are that they are very expensive and that they occur at the beginning of a long rotation period. In the example I presented, the cost was CAN\$1500/ ha. The sensitivity analysis showed that given the other assumptions, stand establishment costs would have to decrease to CAN\$209/ha in order to increase the land expectation value to zero. At this conference, my colleague Vic Lieffers gave a presentation in which he suggested that white spruce regeneration can be encouraged on boreal mixedwood sites using some very inexpensive silvicultural treatments (Lieffers et al. 2012). Natural seeding of white spruce can be encouraged by leaving seed trees in-block or by using a cut-block design that leaves much of the cut-block area within $100 \mathrm{~m}$ of a seed source (Solarik et al. 2010). Mineral soil, which provides a good seedbed for white spruce, can be exposed by dropping the skidder blade on the skidder's return trip to the block.

In this section, I will use some hypothetical (but reasonable) assumptions to evaluate the economics of using inexpensive silviculture to encourage white spruce regeneration on boreal mixedwood sites. In the first example, I assume that the mill-gate value for white spruce is CAN $\$ 60 / \mathrm{m}^{3}$ and that aspen in valueless. The two species grow in an intimate mixture with timber yields growing according to the yield curves shown in Fig. 5. Stand establishment costs are assumed to be negligible and the

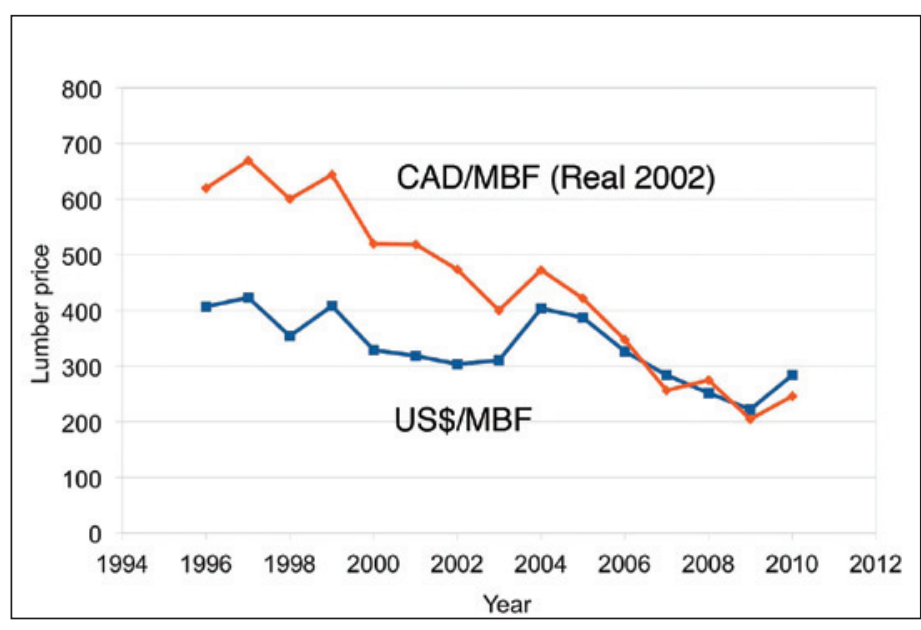

Fig. 2. Average annual composite random lengths lumber prices (US\$/MBF (US\$) and CAN\$/MBF constant 2002 (CAN\$2OO2) dollars). 1996-2010. Source: Random Lengths (Available at http://www. randomlengths.com/In-Depth/Monthly-Composite-Prices) and Statistics Canada.

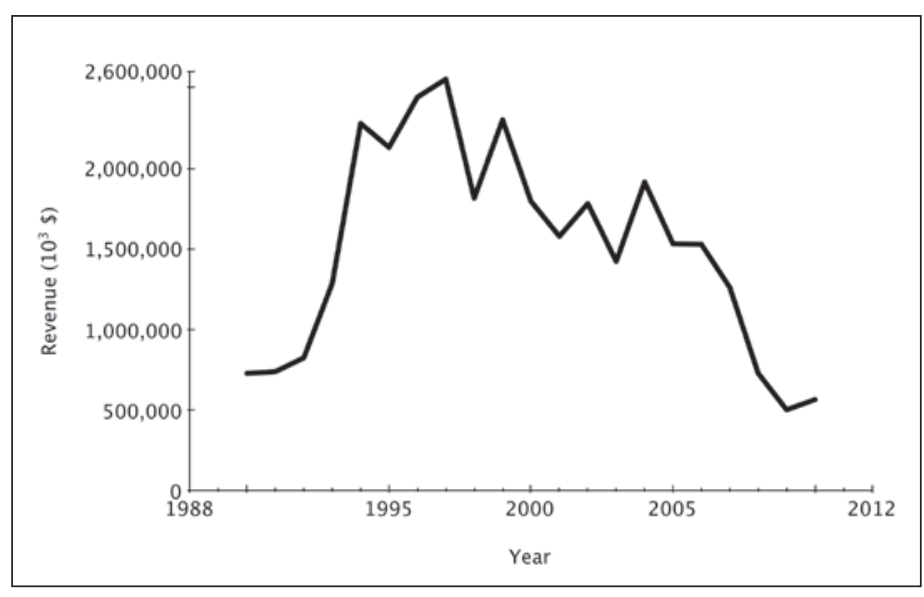

Fig. 3. Crown timber revenue. Canada. 1990-2010. Source: National Forestry Database [online]. Available at http://nfdp.ccfm.org/data/ compendium/html/comp_81e.html [Accessed 31 October 2012].

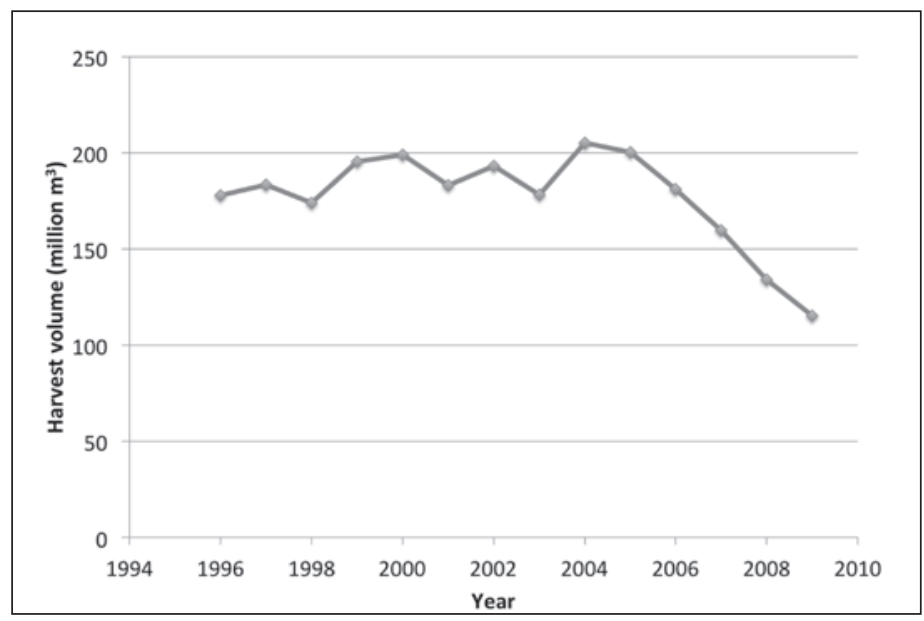

Fig. 4. Roundwood harvest volume. Canada. 1995-2009. Source: National Forestry Database [online]. Available at http://nfdp.ccfm.org/ data/compendium/html/comp_52e.html [Accessed 31 October 2012]. 


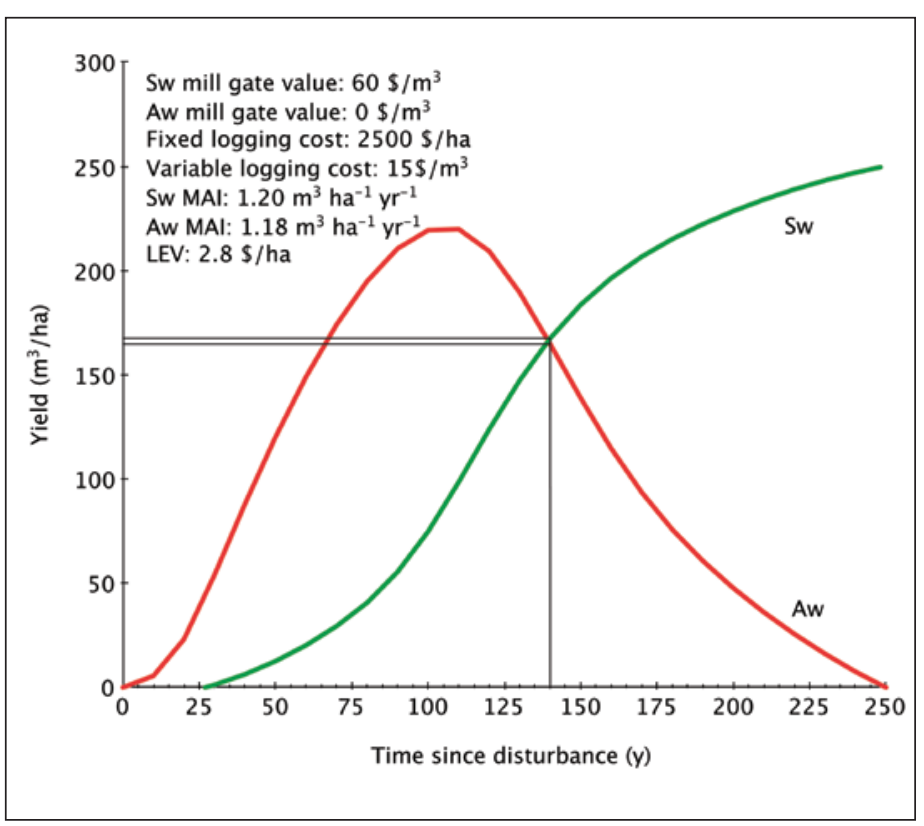

Fig. 5. Calculation of land expectation value for mixedwood stands assuming aspen is worthless.

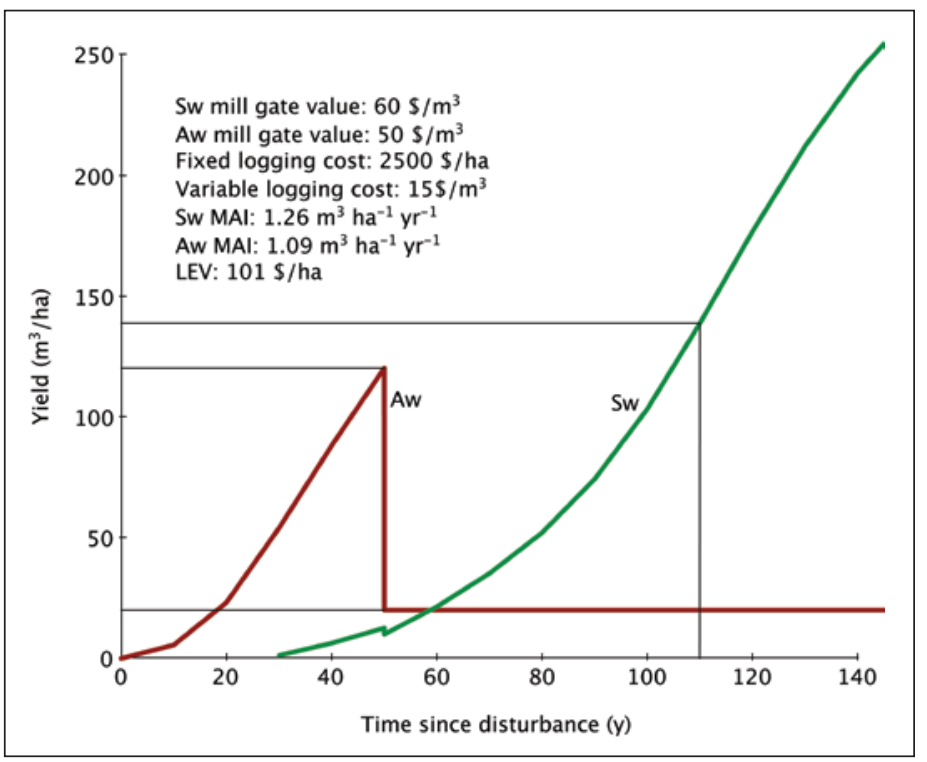

Fig. 6. Calculation of land expectation value for mixedwood stands assuming understory protection harvest with overstory removal at 50 years of age.

discount rate is set at $5 \%$. The optimal economic rotation given these assumptions is 140 years giving a LEV of CAN $\$ 2.68 / \mathrm{ha}$ and softwood and hardwood MAIs of $1.20 \mathrm{~m}^{3} \cdot \mathrm{ha}^{-1} \cdot \mathrm{year}^{-1}$ and $1.18 \mathrm{~m}^{3} \cdot \mathrm{ha}^{-1} \cdot \mathrm{year}^{-1}$, respectively. The LEV is not large, but it is at least non-negative.

The assumption that aspen is worthless is clearly not tenable in Alberta, given the huge increase in aspen harvest volumes over the past 30 years. When the above calculation is repeated using an aspen mill-gate value of CAN $\$ 50 / \mathrm{m}^{3}$ the optimal economic rotation decreases to 50 years and LEV increases to CAN\$217/ha. Softwood and hardwood MAIs are $0.25 \mathrm{~m}^{3} \cdot \mathrm{ha}^{-1} \cdot$ year $^{-1}$ and $2.4 \mathrm{~m}^{3} \cdot \mathrm{ha}^{-1} \cdot$ year $^{-1}$, respectively.
Since the late 1980s in western Canada, there has been discussion about harvesting systems that would allow companies to harvest overstory aspen while retaining most of understory white spruce in boreal mixedwood stands (Brace and Bella 1988, Navratil et al. 1994). These harvesting systems are usually referred to as understory protection systems. At this conference, Gitte Grover described some understory protection systems being tried on the Alberta-Pacific Forest Industries Inc. Forest Management Area in northeastern Alberta, and their projected impact on growth and yield (Grover et al. 2012; see also Grover et al. 2014).

Fig. 6 summarizes the financial analysis for a hypothetical understory protection prescription. Most of the aspen overstory is removed at the optimal single harvest rotation age of 50 years. One-sixth of the aspen volume is left in retention strips. One-fifth of the spruce trees are destroyed during the overstory removal operation as a result of the creation of machine corridors and the harvesting operations. After the overstory removal, the current annual increment for white spruce trees is assumed to increase by $50 \%$ over the base yield curve. A rotation age of 110 years maximizes the LEV at CAN $\$ 101 /$ ha for this prescription. Softwood and hardwood MAIs are $1.26 \mathrm{~m}^{3} \cdot \mathrm{ha}^{-1} \cdot \mathrm{year}^{-1}$ and $1.09 \mathrm{~m}^{3} \cdot \mathrm{ha}^{-1} \cdot$ year $^{1}$, respectively.

The LEV for the understory protection prescription is positive, but it is important to note that it is less than half the value for the single-entry mixedwood harvest prescription. This means that if the goal of the silvicultural treatments is to maximize the net present value of timber production, understory protection is a poor choice given the assumptions used in these calculations. However, this prescription would lead to more spruce on the landscape than the single entry harvest prescription would. There may be other goals of forest management (e.g., diversity of habitats) that may make the understory protection prescription desirable.

\section{Concluding Remarks}

The stand-level analyses conducted for this paper show quite clearly that expensive silviculture to ensure establishment of pure white spruce stands on boreal mixedwood sites in Alberta is a bad investment, if the goal of the investment is to grow commercial timber crops. The land expectation values resulting from these investments are highly negative. The sensitivity analysis presented in Table 1 shows that timber prices or yields would need to be unreasonably high, or that establishment costs or discount rates would need to be unreasonably low to make this kind of investment appear financially attractive.

Inexpensive silvicultural treatments (those relying on natural regeneration) on boreal mixedwood sites can lead to quite attractive LEVs. These generally result in much lower coniferous timber production (as measured by MAI) and a substantial shift towards deciduous timber production. This shift could be mediated somewhat by the implementation of an understory protection harvest system, but at the cost of a substantial reduction in net present value of timber production. This reduction in LEV could be acceptable if non-financial objectives are important to the decision-maker. Even with understory protection, 
the production of softwood timber using inexpensive silviculture is likely to be substantially less than it would be under the status quo. There is economic pressure for companies to shift away from softwood production.

It is clear from the calculations that the standard silvicultural regime for boreal mixedwood sites in Alberta is a terribly bad investment. Why do companies continue to do it? One answer is that harvest rights on public forest land in Alberta are contingent on acceptance of reforestation responsibility. In Alberta, harvesting spruce stands requires a commitment to regenerate spruce stands, regardless of the cost.

Another reason is that the annual allowable cut set by the Alberta Ministry of Environment and Sustainable Resource Development is guided by a model that relates harvest levels to assumptions about the growth of future stands. This is the allowable cut effect (ACE) described by Schweitzer et al. (1972). If a larger current harvest can be accomplished by increasing assumed future yields, it may be worth spending money on expensive silviculture, including silvicultural prescriptions that lead to a negative LEV. In this case, the silvicultural expenditure is not an investment in a future stand; it is a mechanism to justify an immediate increase in the harvest level from existing stands. The ACE is not an artefact of the relatively new optimizing forest planning models-it can be seen in any of the old allowable cut formulas that incorporate assumptions about future growth, including those of Hundeshagen (Davis 1966) and Hanzlik (1922).

The analysis presented in this paper and the conclusions resulting from it are not particularly novel for the boreal mixedwood forest. Armstrong and Phillips (1989), Rodrigues (1998) and Adamowicz et al. (2003) present similar analyses and arguments. Perhaps now is the right time for forest managers to consider these arguments carefully. The profit margins associated with timber harvest and lumber manufacture are very low. Many companies can no longer afford to subsidize the establishment of conifer stands in the boreal forest, even if it means the acceptance of lower current and future harvest levels.

\section{References}

Adamowicz, W.L., G.W. Armstrong and M.J. Messmer. 2003. Chapter 6. The economics of boreal forest management. In P.J. Burton, C. Messier, D.W. Smith and W.L. Adamowicz. Towards sustainable management of the boreal forest. pp. 181-211. NRC Research Press, Ottawa. 1039 p.

Armstrong, G.W. 2011. Alberta timber yield tables [online]. Available at http://optforlab.ca/demos.html [Accessed 9 January 2013].

Armstrong G.W. and W.E. Phillips. 1989. The optimal timing of land use changes from forestry to agriculture. Can. J. Agric. Econ. 37: 135-134.

Bergeron, Y., B. Harvey, A. Leduc and S. Gauthier. 1999. Stratégies d'aménagement forestier qui s'inspirent de la dynamique des perturbations naturelles : considérations l'échelle du peuplement et de la forêt. For. Chron. 75: 55-61.

Brace, L.G. and I.D. Bella. 1988. Understanding the understory: Dilemma and opportunity. In J. Samoil. Management and Utilization of Northern Mixedwoods. pp. 69-86. Northern Forestry Centre, Canadian Forestry Service, Edmonton, AB. Inform. Rep. NOR-X-296.
[CCFM] Canadian Council of Forest Ministers. 2012. National Forestry Database. Forest products - quick facts [online]. Available at http://nfdp.ccfm.org/products/quick_facts_e.php [Accessed 9 January 2013].

Clark J.L. 1985. Thus spoke Chief Seattle: The story of an undocumented speech. Prologue Magazine 18(1). Available at http://www. archives.gov/publications/prologue/1985/spring/chief-seattle.html [Accessed 9 January 2013].

Davis K.P. 1966. Forest Management: Regulation and Valuation. 2nd ed. McGraw-Hill Book Company, New York. 519 p.

Davis, L.S., K.N. Johnson, P. Bettinger and T.E. Howard. 2001. Forest management: to sustain ecological, economic, and social values. McGraw-Hill, Dubuque, IA. 804 p.

Faustmann, M. 1849. Calculation of the value which forest land and immature stands possess for forestry. J. Forest Econ. 1: 7-44. Reprinted in 1995.

Grover, B., K. Greenway and M. Bokalo. 2012. White spruce understory protection: From planning to growth \& yield. presented at Boreal Mixedwoods 2012, Ecology and Management for Multiple Values. June 17-20, 2012 [online]. Available at http://goo.gl/98V6w [Accessed 9 January 2013].

Grover, B.E., M. Bokalo and K.J. Greenway. 2014. White spruce understory protection: From planning to growth and yield. For Chron: 90: 7-15

Hanzlik, E. 1922. Determination of the annual cut on a sustained basis for virgin American forests. J. For. 20: 611-625.

Lieffers, V.J., G.W. Armstrong, K.J. Stadt and E.H. Marenholtz. 2008. Forest regeneration standards: Are they limiting management options for Alberta's boreal mixedwoods? For. Chron. 84: 76-82.

Lieffers, V., S.E. Macdonald, B. Grover, K. Solarik, J. Martin-DeMoor and S. Gärtner. 2012. Natural (and inexpensive) means of regeneration of white spruce in mixedwood boreal forests. Presented at Boreal Mixedwoods 2012, Ecology and Management for Multiple Values, June 17-20, 2012 [online]. Available at http://goo.gl/cNHPE [Accessed 9 January 2013].

Lieffers, V.J., R.B. Macmillan, D. MacPherson, K. Branter and J.D. Stewart. 1996. Semi-natural and intensive silvicultural systems for the boreal mixedwood forest. For. Chron. 72: 286-292.

Mead, D.A. 1977. Aspen - the ugly duckling. For. Chron. 53: 353-354. Navratil, S., L.G. Brace, E.A. Sauder and S. Lux. 1994. Silvicultural and harvesting options to favor immature white spruce and aspen regeneration in boreal mixedwoods. Natural Resources Canada, Canadian Forest Service, Northwest Region, Edmonton, AB. Inform. Rep. NOR-X-337.

Ondro, W.J. 1991. Present trends and future prospects for poplar utilization in Alberta. For. Chron. 67: 271-274.

Peters, V.S., S.E. Macdonald and M.R.T. Dale. 2006. Patterns of initial versus delayed regeneration of white spruce in boreal mixedwood succession. Can. J. For. Res. 36: 1597-1609.

Rodrigues, P.M.J. 1998. Economic analysis of ecologically based mixedwood silviculture at the stand level. Master's thesis, Department of Rural Economy, University of Alberta, Edmonton, AB. 114 p.

Rowe, J.S. 1972. Forest Regions of Canada. Pub. No. 1300. Canadian Forestry Service, Department of Fisheries and the Environment, Government of Canada, Ottawa.

Schweitzer, D.L., R.W. Sassaman and C.H. Schallau. 1972. Allowable cut effect - some physical and economic implications. J. For. 70: 415-418.

Solarik, K.A., V.J. Lieffers, W.J.A. Volney, R. Pelletier and J.R. Spence. 2010. Seed tree density, variable retention, and stand composition influence recruitment of white spruce in boreal mixedwood forests. Can. J. For. Res. 40: 1821-1832. 